\title{
MODEL FOR SIMULATION OF LIFE CYCLE COSTS AT THE STAGE OF PRODUCT DEVELOPMENT
}

\author{
Todic, V.; Cosic, I.; Maksimovic, R.; Tasic, N. \& Radakovic, N. \\ University of Novi Sad, Faculty of Technical Sciences, Trg Dositeja Obradovića 6, 21000 Novi, Sad, \\ Serbia \\ E-Mail: vladimir.todic@uns.ac.rs, ilijac@uns.ac.rs,rado@uns.ac.rs,nemanja.tasic@uns.ac.rs, \\ nikolar@uns.ac.rs
}

\begin{abstract}
Managing the costs of a product life cycle, which is performed at the stage of its development, has a dominant influence on achieving and maintaining the competitiveness of the product in the market and the target profit as the primary production goal. Development is of crucial importance in the product life cycle, because evaluating individual solutions for the new product's conceptual and preliminary design based on the simulation of costs of all stages of its life cycle represents the way of ensuring the design requirements for excellence. This paper presents in detail the setting and development of a hybrid model of product life cycle cost management, based on fuzzy neural networks.

(Received in May 2016, accepted in August 2016. This paper was with the authors 1 month for 1 revision.)
\end{abstract}

Key Words: Product, Product Life Cycle, Cost Simulation, Cost Management

\section{INTRODUCTION}

Life cycle cost management begins at the stage of product development. It is the stage of selection and choice of ideas and evaluation of individual solutions in the process of conceptual and preliminary design [1], i.e. product design development in accordance with the functional and other requirements of the new product on one hand, and comprehensive analysis of competitive products on the market on the other [2].

Development hugely affects the costs of individual stages of product life cycle, particularly the production costs [3], because errors arising at the stage of conceptual and preliminary design can increase production costs by as much as $60 \%$. Therefore, all aspects of costs of production, use and recycling, including the aspects of the total cost of the product should be taken into account as early as the stage of development.

In the modern environment, developing a new product emerges as a result of the work of a competent design team, usually organized on the concept of simultaneous engineering. It involves reaching a solution which is suitable for all stages of the life cycle, from development to recycling. Supporting such a design is based on the use of DFX tools intended for excellence in design [4].

Instruments of strategic cost management related to the cost of the product include cost management in all stages of its life cycle by comparing the costs of the observed product with the costs of the most important competitors. Comparing the product's cost (Cost Benchmarking) with the costs of the most important competitors as the instrument of strategic and operational management enables identifying strengths and weaknesses of the own enterprise in comparison with competition, which determines directions and development strategies of addressing the identified weaknesses.

\section{LITERATURE REVIEW}

There are many traditional and modern methods which can be used to assess the life cycle costs of a new or improved product in the part of the development stage that refers to the 
choice and selection of ideas for a new or improved product, as well as in the assessment of variations in the product's conceptual solutions [5].

Papers presenting a variety of cost assessment methods and models in the last five to six years can be divided into two main groups.

The first group includes papers which present the methods and models of assessing the product life cycle cost, while the second group of papers presents the methods and models for assessing the costs of individual stages of the product life cycle.

The assessment of life cycle costs, or costs of individual stages such as design, production, installation, operation and dismantling [6], is performed at the stage of development using the ABC (Activity Based Costing) method, by disassembling complex products to respective sub-assemblies and parts. In [7], a mathematical model has been developed for assessing the life cycle costs based on regression analysis. Life cycle costs in this model include the costs of product development, production, use and withdrawal.

The model for assessing the costs of development, production, use and withdrawal [8] is characterized by the division of development costs into planned and stochastic costs, as well as by the uncertainty in the assessment of costs of use. The costs of removal in this model are characterized by four management strategies, such as the cost of recycling, reuse of some parts, remanufacturing and costs of permanent removal.

In [9], the influence of the product's material on its structure and dimensions, and hence the manufacturing and assembly costs was determined using the PBC analysis. The paper [10] presents a model for assessing the costs of production using artificial neural networks and genetic algorithms.

In assessing the costs of production using artificial neural networks and regression analysis, which is based on the Taylor Kriging method [11], a sensitivity analysis was applied to determine the share of costs with the highest influence on overall production costs.

The paper [12] presents a model for assessing the costs of production using artificial neural networks, depending on the structure of product complexity.

The paper [13] presents the results obtained by applying two types of artificial neural networks to assess the costs of production in the product development stage, indicating that product development can affect the production costs by up to $80 \%$.

The assessment of production costs based on the principle of variation management using the ABC (Activity Based Costing) method [14] includes tolerance allocation diagrams, process plan, resource allocation and diagrams of activities of process planning and scheduling. The influence of processing tolerance on the corresponding processing costs has been determined using the Taguchi function and parametric equations.

In the hybrid model, which is based on fuzzy neural networks, a tolerance cost model has been developed to assess the costs of processing [15]. In this model, the cost function, which can be of exponential, linear, reciprocal and combined form, is defined depending on the processing tolerance and weight coefficients of influential factors such as tools, processing methods, sequence of procedures, processing time, method of measurement, and skills of the operator.

The paper [16] presents the comparative features of intuitive, analogue, parametric and analytical methods of assessing the costs of production and use. The paper specifically emphasizes the importance of assessing the cost of use of long-run products of high-value.

The application of regression analysis to assess the costs of development, production, marketing and recycling [17-19] shows that statistical analysis provides the best results in the assessment of these costs.

The flow of analysis of costs of development and production processes by combining partial optimization and feedback neural networks is presented in [20]. 
Compared to models that are presented in the cited literature, developed hybrid model of product life cycle cost management manages the costs of development, production, use and recycling, as well as the total costs of the product life cycle.

\section{METHODOLOGY AND DEVELOPMENT OF COSTS MANAGEMENT MODEL FOR NEW PRODUCT}

The hybrid model of product life cycle cost management has been set up and developed methodologically based on the application of fuzzy neural networks. The results and significance of studies related to the development of methods and models for assessing the product life cycle cost reported by a significant number of papers were considered during the process.

Hybrid neural fuzzy systems make the modern class of these systems in which neural networks and the fuzzy system represents a homogeneous structure. These systems can be conditionally seen as a neural network characterized by fuzzy parameters. This is the type of architecture used by the widely used adaptive neural fuzzy networks or ANFIS (Adaptive Neural Fuzzy Inference System).

The functional structure of the adopted model is characterized by six stages (Fig. 1). The first stage relates to the choice and the name, as well as the label of the new product. The second stage relates to the conceptual and preliminary design of the previously selected new product, including defining the product's parameters and performances, while the third stage refers to the selection of a group of similar products for comparison whose corresponding costs of life cycle by stages are known.

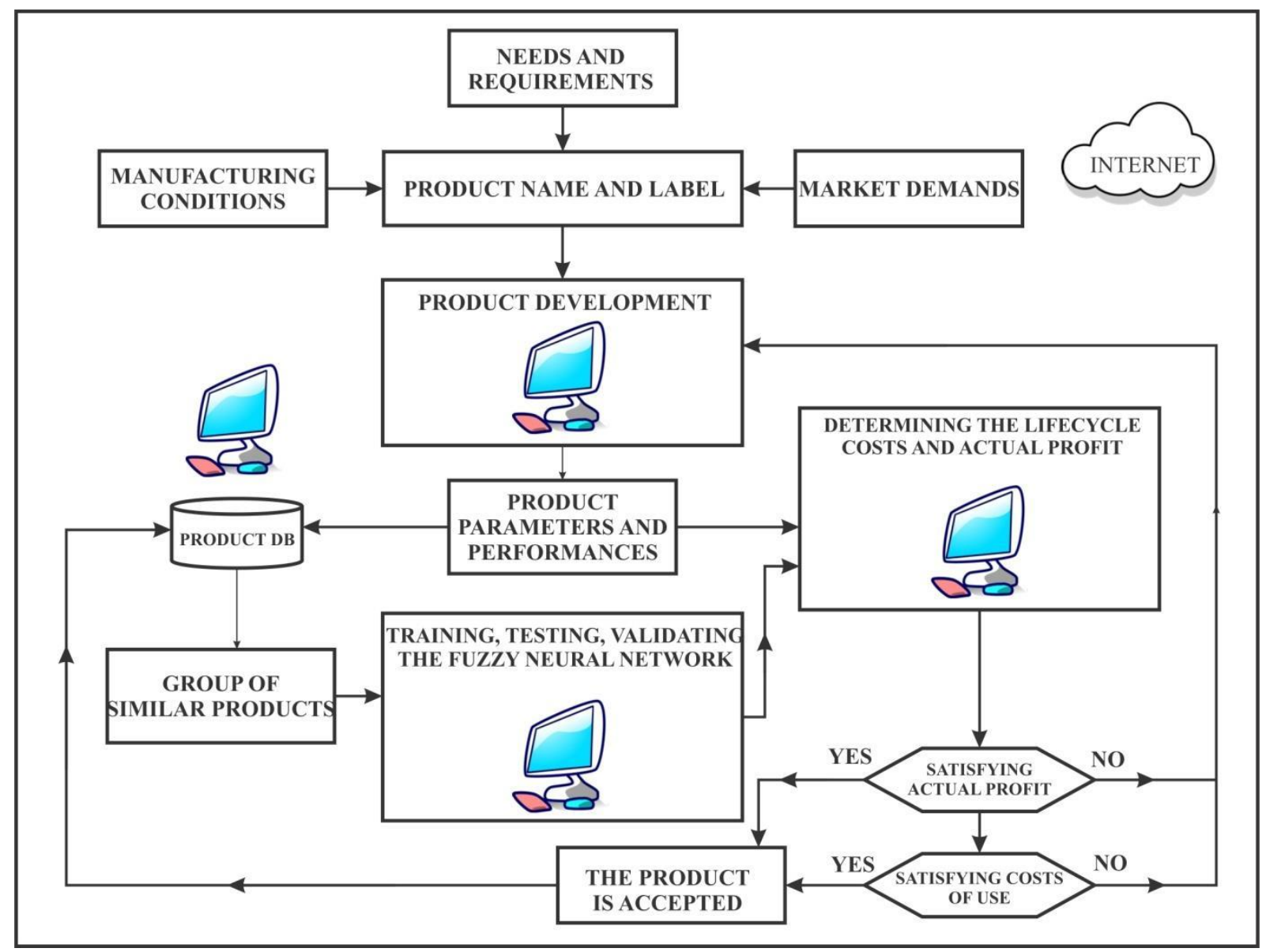

Figure 1: Hybrid model of product life cycle cost management. 
The selection of a group of similar products based on the label of a new product, whose similarity with the new product is based on structural and technological issues, or principles of group and typological technology [21], can be performed using adequate, usually internal classifiers, or in automated manner. The automated identification and selection of similar products or their parts is based on the application of the STEP standard (ISO 10303-STEP) for designing of parts using standardized shapes [22].

In the application of the developed model of life cycle cost management of complex new products which consist of several parts, the corresponding group of similar products is usually chosen based on: 1) expert knowledge and knowledge of functional structure and performances of the corresponding type of products and their technological process of production, and 2) internal or some other system of labelling complex products in the observed enterprise.

The fourth stage includes training, testing and validating the selected fuzzy neural network [5]. Training, testing and validating the fuzzy neural network is performed based on the costs of stages of development, production, usage and recycling of the selected groups of similar products individually for each stage for which these costs are known. The life cycle costs of similar products, realized in specific production conditions, make the central part of the developed model.

The fifth stage refers to determining the cycle costs and actual profits of the new product, with the sixth stage relating to the evaluation of the new product which emerges in the stage of conceptual and preliminary design development. The evaluation is based on the target profit, as determined by the observed company, as well as usage and recycling costs.

Since the market price $\left(C_{T}\right)$ and the costs of development and production of the new product $\left(T_{r a}+T_{p r}\right)$ determine the actual profit $(P)$, product evaluation implies a solution for conceptual and preliminary design of new product for which the actual profit is higher or equal to the target profit. The actual profit is determined on the basis of the following expression:

$$
P=C_{T}-\left(T_{r a}+T_{p r}\right)
$$

If the costs of development and production $\left(T_{r a}+T_{p r}\right)$ provided by the observed new product solution prevent the achievement of the target profit, the conceptual and preliminary product design should be altered or improved, or a new production processes developed [23].

In addition to primary management which refers to managing target costs or costs of development and production that allow the achievement of the target profit, the process of cost management also includes managing the costs of use $\left(T_{u p}\right)$ [24]. This is performed by comparing these costs of the observed product with the corresponding costs of the competitor's product $\left(T_{u p k}\right)$, namely:

$$
T_{u p} \leq T_{u p k}
$$

Ensuring the conditions from (2) by developing an appropriate structure for the new product or a technological process which is unlikely to threaten the target profit, a higher level of competitiveness can be achieved for the product on the market. In the case when conditions (1) and (2) are met the product is approved, provided that condition (2) is not a limiting factor in relation to condition (1). When these conditions are unlikely to be met, the structure of the conceptual and preliminary product design should be altered or the production process improved.

Moreover, in the process of product life cycle cost management, in addition to conditions described by expressions (1) and (2), in general case, the solution of conceptual and preliminary design for the new product for which the recycling costs are the lowest will be adopted. 


\section{APPLICATION OF THE DEVELOPED MODEL}

The developed algorithm is based on the selection of a group of similar products in the observed company for which the costs of the stages of development, production, use and recycling are known. The costs of development and production are located in the appropriate database of observed company.

The product costs of usage are collected and systematized on the basis of the data of users of these products. The costs of recycling are adopted and systematized based on the recommendations of specialized companies for recycling.

Constructional and technological similarity of the products, covered in the observed example, and the similarity of the products for which the life cycle costs are known, are the basic advantage of the capability of the developed algorithm to manage the life cycle costs of new products.

The developed hybrid model was applied for assessing the economic feasibility of producing single row angular contact ball bearings as a new product, Fig. 2, whose dimensions are presented in Table I, and for which the observed enterprise has production capabilities and possibility of placement on the market.

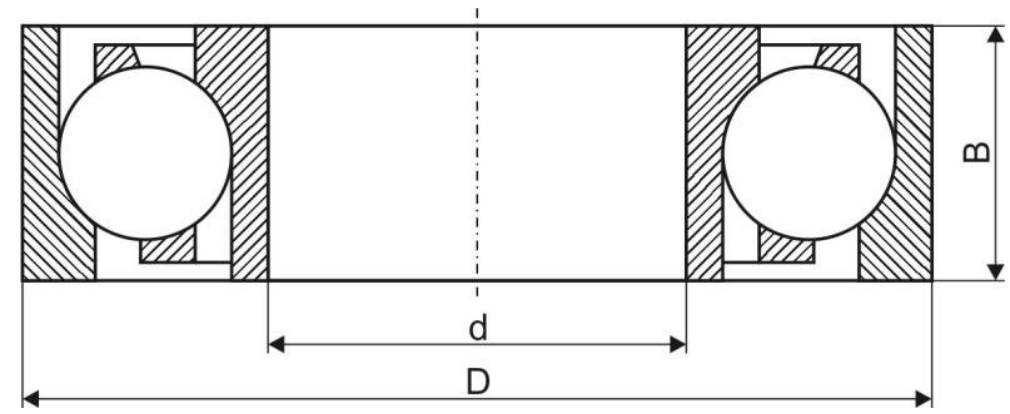

Figure 2: Single row angular contact ball bearing.

According to the present model, after collecting the data and analysing the market regarding placement possibilities of the aforementioned bearings, it is necessary to define their parameters as the basic input data, which consist of, Fig. 2:
- Bore diameter
$d(\mathrm{~mm})$,
- Outer diameter $D(\mathrm{~mm})$,
- Bearing width $B(\mathrm{~mm})$,
- Bearing mass $m(\mathrm{~kg})$.

Table I: Dimensions of single row angular contact ball bearings.

\begin{tabular}{|c|c|c|c|c|c|}
\hline \multirow{2}{*}{ No. } & \multicolumn{4}{|c|}{ Bearing dimensions and mass } & \multirow{2}{*}{ Label } \\
\cline { 2 - 5 } & $d$ & $D$ & $B$ & $m$ & \\
\hline 1. & 90 & 160 & 30 & 2.30 & $7218 \mathrm{BE}$ \\
\hline 2. & 100 & 180 & 34 & 3.30 & $7220 \mathrm{BE}$ \\
\hline 3. & 105 & 190 & 36 & 3.95 & $7221 \mathrm{BE}$ \\
\hline 4. & 110 & 200 & 38 & 4.60 & $7222 \mathrm{BE}$ \\
\hline 5. & 120 & 215 & 40 & 6.10 & $7224 \mathrm{BE}$ \\
\hline 6. & 130 & 230 & 40 & 6.95 & $7226 \mathrm{BE}$ \\
\hline
\end{tabular}

The production of the above new rolling bearing, for which the design solutions and materials are usually imposed by customer requirements or standards for this type of product, will be implemented in the existing manufacturing conditions of the company in amounts corresponding to series production. 


\subsection{Selection and presentation of similar bearings from the current production program}

The costs of individual life cycle stages of the selected group of similarly realized products in the observed company were determined based on the corresponding activities as cost inducers, Table II.

Table II: Life cycle activities of rolling bearings by stages.

\begin{tabular}{|l|l|l|l|}
\hline \multicolumn{5}{|c|}{ Life cycle activities of rolling bearings by stages } \\
\hline Product development & \multicolumn{1}{|c|}{ Production } & \multicolumn{1}{c|}{ Use } & \multicolumn{1}{c|}{ Recycle } \\
\hline - Product planning & - Managing the & - Assembly, or & - Product withdrawal \\
- Conceptual design & company & installing the & - Dismantling \\
- Modelling & - Marketing & bearing & - Sorting the \\
- Structural & management & & components \\
- development & - Development & & - Selecting parts for \\
- Process selection & process & & re-use \\
- Prototype & - Commercial affairs & & - Washing and \\
- Testing & - Manufacturing & & degreasing \\
- Validating & process & & - Recycling \\
- Zero series, etc. & - Managing the & & Removing the \\
& finances & & \\
& - Human resource & & \\
& - management & & \\
& Logistics & & \\
\end{tabular}

A group of similar products of this kind for which the costs of individual life cycle stages are known has been selected using the company's internal classifier, Table III. The selection was based on the analysis of the design solution and planned production volume of the single row angular contact ball bearings whose dimensions are given in Table I, as well as the analysis of design solutions and technological processes of producing rolling bearings from the current production program of the observed company.

According to the internal classifier of the observed specialized company for the production of rolling bearings single row angular contact ball bearings as a new product belong to a group of similar bearings from the current production programme.

The group consists of radial single row ball bearings classified into six standard groups with the corresponding range of dimensions, labelled 172, UE, LE, UY, LY, LN, and a group of single and double row radial ball bearings, which consists of eighteen different bearing design solutions which are produced in single dimension, intended for agricultural machinery.

The costs of development and production $\left(T_{r a}+T_{p r}\right)$ of the selected groups of similarly realized bearings are located in the database of products in the observed enterprise, while the costs use and recycling were identified primarily based on the recommendations of users of these products, as well as specialized recycling companies.

The costs of use $\left(T_{u p}\right)$ of bearings include the costs of installing them in the corresponding products, either as first installation or spare part to products which are in use. Bearings are delivered to the market ready to be installed and used.

For the purpose of collecting data on the costs of installation of rolling bearings, certain manufacturers of new products that incorporate rolling bearings were consulted, including the automotive industry, as well as the industry of agricultural machinery. Moreover, data was collected on the costs of installing bearings in car repair businesses, companies for servicing agricultural machinery and other technical products. 
Todic, Cosic, Maksimovic, Tasic, Radakovic: Model for Simulation of Life Cycle Costs at ...

Table III: Life cycle costs of the selected group of similarly realized bearings.

\begin{tabular}{|c|c|c|c|c|c|c|c|c|c|}
\hline \multirow{3}{*}{ No. } & \multirow{2}{*}{\multicolumn{4}{|c|}{ Bearing dimensions and mass }} & \multirow{3}{*}{ Label } & \multicolumn{4}{|c|}{ Life cycle costs of bearings ( $€ /$ piece $)$} \\
\hline & & & & & & \multirow{2}{*}{$\begin{array}{c}\text { Development } \\
T_{r a}\end{array}$} & \multirow{2}{*}{$\begin{array}{c}\text { Manufacturing } \\
T_{p r}\end{array}$} & \multirow{2}{*}{$\begin{array}{l}\text { Use } \\
T_{u p}\end{array}$} & \multirow{2}{*}{$\frac{\text { Recycling }}{T_{r e}}$} \\
\hline & $d$ & $D$ & $B$ & $m$ & & & & & \\
\hline 1. & 15 & 35 & 11 & 0.04 & 1726202-2RSI & 0.38 & 2.05 & 1.37 & 0.36 \\
\hline 2. & 17 & 40 & 12 & 0.06 & 1726203-2RS1 & 0.31 & 1.69 & 1.13 & 0.30 \\
\hline 3. & 20 & 47 & 14 & 0.10 & 1726204-2RS1 & 0.27 & 1.49 & 1.00 & 0.28 \\
\hline 4. & 25 & 52 & 15 & 0.11 & 1726205-2RS1 & 0.52 & 2.79 & 1.87 & 0.50 \\
\hline 5. & 30 & 62 & 16 & 0.18 & $1726206-2 \mathrm{RS} 1$ & 0.28 & 1.56 & 1.05 & 0.32 \\
\hline 6. & 35 & 72 & 17 & 0.25 & 1726207-2RS1 & 0.80 & 4.35 & 2.91 & 0.80 \\
\hline 7. & 40 & 80 & 18 & 0.32 & $1726208-2 \mathrm{RS} 1$ & 0.41 & 2.24 & 1.50 & 0.47 \\
\hline 8. & 45 & 85 & 19 & 0.37 & 1726209-2RS1 & 1.13 & 6.14 & 4.11 & 1.14 \\
\hline 9. & 50 & 90 & 20 & 0.41 & 1726210-2RS1 & 0.56 & 3.06 & 2.05 & 0.64 \\
\hline 10. & 55 & 100 & 21 & 0.56 & 1726211-2RS1 & 1.46 & 7.93 & 5.31 & 1.50 \\
\hline 11. & 60 & 110 & 22 & 0.75 & $1726212-2 \mathrm{RS} 1$ & 1.67 & 9.05 & 6.06 & 1.74 \\
\hline 12. & 65 & 120 & 23 & 0.94 & 1726213-2RS1 & 1.88 & 10.2 & 6.83 & 1.99 \\
\hline 13. & 12 & 40 & 22.1 & 0.09 & UE 203/12 $2 \mathrm{~S}$ & 0.42 & 2.33 & 1.56 & 0.42 \\
\hline 14. & 20 & 47 & 25.5 & 0.11 & UE $2042 \mathrm{~S}$ & 0.40 & 2.20 & 1.47 & 0.40 \\
\hline 15. & 25 & 52 & 27.2 & 0.14 & UE 2052 S & 0.46 & 2.56 & 1.72 & 0.47 \\
\hline 16. & 30 & 62 & 33 & 0.23 & UE $2062 \mathrm{~S}$ & 0.72 & 3.97 & 2.66 & 0.73 \\
\hline 17. & 35 & 72 & 33 & 0.31 & UE $2072 \mathrm{~S}$ & 0.94 & 5.17 & 3.46 & 0.96 \\
\hline 18. & 40 & 80 & 36 & 0.43 & UE $2082 \mathrm{~S}$ & 1.18 & 6.48 & 4.34 & 1.21 \\
\hline 19. & 45 & 85 & 37 & 0.48 & UE 209 2S & 1.30 & 7.18 & 4.81 & 1.35 \\
\hline 20. & 50 & 90 & 38.8 & 0.54 & UE $2102 \mathrm{~S}$ & 1.41 & 7.78 & 5.21 & 1.47 \\
\hline 21. & 12 & 40 & 27.4 & 0.09 & LE 203/12 2F.SH & 0.61 & 3.31 & 2.22 & 0.58 \\
\hline 22. & 25 & 52 & 34.1 & 0.17 & LE $2052 \mathrm{~F}$ & 0.70 & 3.82 & 2.56 & 0.69 \\
\hline 23. & 30 & 62 & 38.1 & 0.28 & LE $2062 \mathrm{~F}$ & 0.61 & 3.37 & 2.26 & 0.65 \\
\hline 24. & 35 & 72 & 42.9 & 0.41 & LE $2072 \mathrm{~F}$ & 1.04 & 5.64 & 3.78 & 1.07 \\
\hline 25. & 40 & 80 & 49.2 & 0.55 & LE $2082 \mathrm{~F}$ & 0.83 & 4.54 & 3.04 & 0.93 \\
\hline 26. & 45 & 85 & 49.2 & 0.60 & LE $2092 \mathrm{~F}$ & 1.40 & 7.52 & 5.04 & 1.44 \\
\hline 27. & 50 & 90 & 51.6 & 0.69 & LE $2102 \mathrm{~F}$ & 1.13 & 6.20 & 4.15 & 1.25 \\
\hline 28. & 55 & 100 & 55.6 & 0.94 & LE 211 2F & 2.04 & 11.08 & 7.42 & 2.14 \\
\hline 29. & 60 & 110 & 65.1 & 1.30 & LE $2122 \mathrm{~F}$ & 1.95 & 10.75 & 7.20 & 2.19 \\
\hline 30. & 65 & 120 & 68.3 & 1.70 & LE $2132 \mathrm{~F}$ & 3.15 & 17.07 & 11.44 & 3.37 \\
\hline 31. & 70 & 125 & 69.9 & 1.90 & LE 214 2F & 3.42 & 18.79 & 12.59 & 3.72 \\
\hline 32. & 75 & 130 & 73.3 & 2.10 & LE $2152 \mathrm{~F}$ & 3.85 & 21.19 & 14.20 & 4.18 \\
\hline 33. & 80 & 140 & 77.8 & 2.80 & LE $2162 \mathrm{~F}$ & 6.58 & 35.74 & 23.95 & 6.83 \\
\hline 34. & 85 & 150 & 81 & 3.30 & LE $2172 \mathrm{~F}$ & 4.07 & 22.41 & 15.01 & 4.74 \\
\hline 35. & 90 & 160 & 89 & 4.10 & LE $2182 \mathrm{~F}$ & 10.70 & 58.08 & 38.91 & 10.96 \\
\hline 36. & 100 & 180 & 98.4 & 5.65 & LE $2202 \mathrm{~F}$ & 13.18 & 71.54 & 47.93 & 13.68 \\
\hline 37. & 110 & 240 & 117 & 15.1 & LE 322 2F & 18.48 & 101.64 & 68.10 & 21.55 \\
\hline 38. & 120 & 215 & 73.5 & 6.20 & LE $2242 \mathrm{~F}$ & 10.60 & 58.29 & 39.05 & 11.62 \\
\hline 39. & 12 & 40 & 28.6 & 0.09 & UY 203/12 2S.SH & 0.65 & 3.52 & 2.36 & 0.62 \\
\hline 40. & 20 & 47 & 31 & 0.11 & UY $2042 \mathrm{~S}$ & 0.71 & 3.87 & 2.59 & 0.68 \\
\hline 41. & 25 & 52 & 31 & 0.14 & UY $2052 \mathrm{~S}$ & 0.55 & 3.03 & 2.03 & 0.55 \\
\hline 42. & 30 & 62 & 35.7 & 0.23 & UY $2062 \mathrm{~S}$ & 0.92 & 5.01 & 3.36 & 0.91 \\
\hline 43. & 35 & 72 & 38.9 & 0.31 & UY $2072 \mathrm{~S}$ & 0.74 & 4.08 & 2.73 & 0.77 \\
\hline 44. & 40 & 80 & 43.7 & 0.43 & UY $2082 \mathrm{~S}$ & 1.36 & 7.40 & 4.96 & 1.37 \\
\hline 45. & 45 & 85 & 43.7 & 0.48 & UY $2092 \mathrm{~S}$ & 1.08 & 5.93 & 3.97 & 1.14 \\
\hline 46. & 50 & 90 & 43.7 & 0.54 & UY $2102 \mathrm{~S}$ & 1.75 & 9.50 & 6.37 & 1.75 \\
\hline 47. & 55 & 100 & 48.4 & 0.98 & UY $2112 \mathrm{~S}$ & 1.53 & 8.40 & 5.63 & 1.7 \\
\hline 48. & 60 & 110 & 53.3 & 1.30 & UY $2122 \mathrm{~S}$ & 2.81 & 15.26 & 10.22 & 2.95 \\
\hline 49. & 12 & 40 & 37.3 & 0.162 & LY 203/12 2F & 0.41 & 2.24 & 1.50 & 0.42 \\
\hline 50. & 20 & 47 & 43.7 & 0.19 & LY $2042 \mathrm{~F}$ & 0.63 & 3.44 & 2.30 & 0.63 \\
\hline 51. & 25 & 52 & 44.4 & 0.23 & LY $2052 \mathrm{~F}$ & 0.66 & 3.62 & 2.43 & 0.68 \\
\hline 52. & 30 & 62 & 48.4 & 0.43 & LY $2052 \mathrm{~F}$ & 0.65 & 3.51 & 2.35 & 0.72 \\
\hline 53. & 35 & 72 & 51.1 & 0.68 & LY $2062 \mathrm{~F}$ & 1.13 & 6.12 & 4.10 & 1.23 \\
\hline 54. & 40 & 80 & 56.3 & 0.8 & LY $2072 \mathrm{~F}$ & 1.35 & 7.32 & 4.90 & 1.47 \\
\hline 55. & 45 & 85 & 56.3 & 1.08 & LY 208 2F & 1.59 & 8.60 & 5.76 & 1.76 \\
\hline 56. & 50 & 90 & 62.7 & 1.44 & LY $2092 \mathrm{~F}$ & 1.89 & 10.22 & 6.85 & 2.14 \\
\hline 57. & 55 & 100 & 71.4 & 1.86 & LY $2102 \mathrm{~F}$ & 2.03 & 11.04 & 7.40 & 2.41 \\
\hline 58. & 60 & 110 & 77.8 & 2.34 & LY $2112 \mathrm{~F}$ & 2.67 & 14.52 & 9.73 & 3.13 \\
\hline 59. & 65 & 120 & 85.7 & 2.95 & LY $2122 \mathrm{~F}$ & 3.47 & 18.82 & 12.61 & 4.04 \\
\hline 60. & 70 & 125 & 85.7 & 3.67 & LY $2132 \mathrm{~F}$ & 4.17 & 22.65 & 15.18 & 4.89 \\
\hline 61. & 75 & 130 & 92.1 & 4.40 & LY $2142 \mathrm{~F}$ & 4.99 & 27.08 & 18.14 & 5.86 \\
\hline 62. & 80 & 140 & 100 & 2.90 & LY $2152 \mathrm{~F}$ & 6.58 & 35.74 & 23.95 & 6.86 \\
\hline 63. & 90 & 150 & 106 & 3.54 & LY $2162 \mathrm{~F}$ & 7.87 & 42.72 & 28.62 & 8.22 \\
\hline 64. & 100 & 180 & 75 & 4.35 & LY $2202 \mathrm{~F}$ & 7.18 & 39.50 & 26.47 & 7.92 \\
\hline 65. & 110 & 240 & 141.3 & 17.20 & LY 222 2F & 8.58 & 47.19 & 31.62 & 13.06 \\
\hline
\end{tabular}


Todic, Cosic, Maksimovic, Tasic, Radakovic: Model for Simulation of Life Cycle Costs at ...

\begin{tabular}{|l|c|c|c|c|c|c|c|c|c|}
\hline 66. & 120 & 215 & 81 & 6.70 & LY 224 2F & 10.60 & 58.29 & 39.05 & 11.77 \\
\hline 67. & 20 & 47 & 34.1 & 0.16 & LN 204 2F & 0.62 & 3.34 & 2.24 & 0.61 \\
\hline 68. & 25 & 52 & 34.9 & 0.17 & LN 205 2F & 0.49 & 2.71 & 1.82 & 0.50 \\
\hline 69. & 30 & 62 & 36.5 & 0.30 & LN 206 2F & 0.83 & 4.48 & 3.00 & 0.84 \\
\hline 70. & 35 & 72 & 37.7 & 0.49 & LN 207 2F & 0.97 & 5.32 & 3.56 & 1.04 \\
\hline 71. & 40 & 80 & 42.9 & 0.58 & LN 208 2F & 0.99 & 5.39 & 3.61 & 1.08 \\
\hline 72. & 45 & 85 & 42.9 & 0.66 & UE 208 2F & 1.18 & 6.48 & 4.34 & 1.28 \\
\hline 73. & 50 & 90 & 42.9 & 0.76 & LN 209 2F & 1.37 & 7.45 & 4.99 & 1.48 \\
\hline 74. & 60 & 110 & 61.9 & 1.52 & LN 2102F & 1.57 & 8.51 & 5.70 & 1.88 \\
\hline 75. & 70 & 125 & 68.2 & 2.25 & LN 214 2F & 4.37 & 23.71 & 15.89 & 4.65 \\
\hline 76. & 30 & 62 & 30 & 0.39 & FKL 306230 & 0.65 & 3.53 & 2.37 & 0.71 \\
\hline 77. & 35 & 72 & 34 & 0.54 & FKL 357234 A & 1.01 & 5.45 & 3.65 & 1.07 \\
\hline 78. & 30 & 62 & 23.8 & 0.285 & 3206 B.2RS1 & 0.77 & 4.21 & 2.82 & 0.79 \\
\hline 79. & 50 & 90 & 51.6 & 0.70 & LE 210 2TB & 1.19 & 6.49 & 4.35 & 1.30 \\
\hline 80. & 20 & 47 & 20.6 & 0.16 & 3204 B.2RS1 & 0.62 & 3.37 & 2.26 & 0.61 \\
\hline 81. & 20 & 47 & 25.2 & 0.185 & 3204 T & 0.65 & 3.55 & 2.38 & 0.65 \\
\hline 82. & 30 & 62 & 50 & 0.50 & 5206 KPP3 & 1.33 & 7.22 & 4.84 & 1.36 \\
\hline 83. & 17 & 47 & 24.2 & 0.20 & SL 3303 2S & 0.42 & 2.28 & 1.53 & 0.44 \\
\hline 84. & 16 & 40 & 43.88 & 0.218 & SL 5203 2T & 0.52 & 2.84 & 1.90 & 0.54 \\
\hline 85. & 16 & 45 & 18.67 & 0.23 & 06 C04-2Z & 0.38 & 2.05 & 1.37 & 0.41 \\
\hline 86. & 16 & 40 & 18.29 & 0.08 & Q 203 PP.AH02 & 0.39 & 2.13 & 1.43 & 0.38 \\
\hline 87. & 13 & 40 & 18.29 & 0.091 & Q 203 PP.AH05 & 0.40 & 2.13 & 1.45 & 0.39 \\
\hline 88. & 16 & 53 & 19.4 & 0.28 & SL 5316 2T & 0.60 & 3.28 & 2.20 & 0.63 \\
\hline 89. & 19 & 52 & 21.1 & 0.28 & 205 KRP2 & 0.65 & 3.51 & 2.35 & 0.67 \\
\hline 90. & 60 & 130 & 68.4 & 2.97 & LY 312 2F & 2.33 & 12.58 & 8.43 & 3.00 \\
\hline 91. & 50 & 81 & 30 & 0.42 & 209 KRR K/50.135 & 1.69 & 9.19 & 6.16 & 1.67 \\
\hline 92. & 38 & 90 & 30 & 0.80 & 210 RRB6 & 2.83 & 15.37 & 10.30 & 2.81 \\
\hline 93. & 31 & 80 & 36.5 & 0.67 & W 208 PPB16 & 2.74 & 14.89 & 9.98 & 2.70 \\
\hline
\end{tabular}

Based on the information collected, the main factors affecting the costs of their installation were identified, such as:

- Place where it is installed in the product,

- The level of automation and mechanization of installation or assembly,

- Dimensions of the bearing,

- Mass of the bearing, etc.

Taking into account the above factors, Table III shows the recommended average values of costs of installation of the observed bearings.

The costs of recycling $\left(T_{r e}\right)$ were determined by the costs of corresponding activities or costs inducers, which are given in Table II.

The average costs of recycling, which depend mostly on dimensions and mass of the bearing, Table III, are adopted based on the recommendations of specialized recycling companies, and refer to the costs of collecting, removing the bearings from respective products, dismantling, sorting, washing, degreasing, selecting parts for reuse such as bolts and rings, as well as the costs of melting steel and plastic parts and costs of permanent deposition of waste materials.

The costs of melting steel parts are determined based on the following expression:

$$
T_{r e 1}=c_{1} \times m
$$

where: $m$-mass of steel parts, $c_{1}-$ costs of melting steel material per kilogram $\left(c_{1}=0.25 € / \mathrm{kg}\right)$.

The costs of recycling cages and seals, as recommended by specialized companies, are determined in the amount of about $2 \%$ of costs of melting steel parts.

\subsection{Determining the life cycle costs of the observed bearing}

The life cycle costs of the single row angular contact ball bearing in the developed model were determined by using fuzzy neural networks, or the ANFIS model, which was developed in the MATLAB software package.

Based on the input data for the selected group of realized similar bearings, Table III, the degrees of correlation of inputs bearings were determined referring to the bore diameter $(d)$, 
outer diameter $(D)$, width $(B)$ and mass $(m)$ and the bearing's life cycle costs by stages. Thus, it can be concluded that there is a high degree of correlation between the aforementioned input dimensions of the selected group of bearings and the cost of life cycle by stages, Table IV.

Table IV: Correlation factors between the input dimensions and costs of the selected bearings by stages of life cycle (on the scale from 0 to 1 ).

\begin{tabular}{|c|c|c|c|c|}
\hline Input data & Development & Manufacturing & Use & Recycling \\
\hline$d$ & 0.89 & 0.85 & 0.85 & 0.85 \\
\hline$D$ & 0.89 & 0.89 & 0.89 & 0.90 \\
\hline$B$ & 0.79 & 0.78 & 0.78 & 0.81 \\
\hline$m$ & 0.85 & 0.85 & 0.85 & 0.90 \\
\hline
\end{tabular}

As input variables $D, d, B, m$ referring to the outer diameter $(D)$, bore diameter $(d)$, the width $(B)$ and the mass $(m)$ of bearings affect the cost of all phases of the life cycle of the products under consideration.

Multicollinearity of input variables, such as $D, d, B, m$ and costs of product life cycle observed in the case are logical as these variables determine the structural form and characteristics of the products under consideration and cannot be eliminated.

Training, testing and validating the aforementioned fuzzy neural network was performed for each stage of the life cycle on the basis of corresponding input data and systematized data on the costs of the stages of life cycle of the selected group consisting of 93 bearings, Table III. The trained neural network was tested using the data for ten bearings from the aforementioned group, while validation was performed using another group of ten bearings.

The fuzzy neural network was trained using a shifted Gaussian function (gauss $2 \mathrm{mf}$ ), as membership function, with parameters (1 3334 ), while the range of input relevant parameters in which the training was performed is:

- $d=(12-120) \mathrm{mm}$,

- $D=(35-240) \mathrm{mm}$,

- $B=(11-141) \mathrm{mm}$, and

- $m=(0.04-17) \mathrm{kg} /$ bearing.

The application of artificial neural networks has shown good results in solving problems which are based on the experimental data, while fuzzy logic has the ability to solve problems that are based on imprecise data, but cannot independently generate rules by which that information is processed. Therefore, new hybrid models that represent the extension of the fuzzy logic and artificial neural system model are being developed.

Membership function (gauss2mf) that was used to obtain the desired output is a combination of two different Gaussian curve, where one side is angled. The membership function has parameters (l $\left.\begin{array}{llll}1 & 3 & 3 & 4\end{array}\right)$, whose multiplication represents the number of rules by which the fuzzy neural network is trained, tested and validated.

In the training of the fuzzy neural network a small number of negative numerical cost values appear, arising from inaccuracies of the program used. These values, as being illogical, were removed before determining the life cycle costs of the new product.

As an illustration, the paper provides a graphical presentation of production costs $\left(T_{p r}\right)$ depending on the input data relating to bore diameter $(d)$, outer diameter $(D)$, width $(B)$ and mass $(m)$ of the bearing, Fig. 3. 


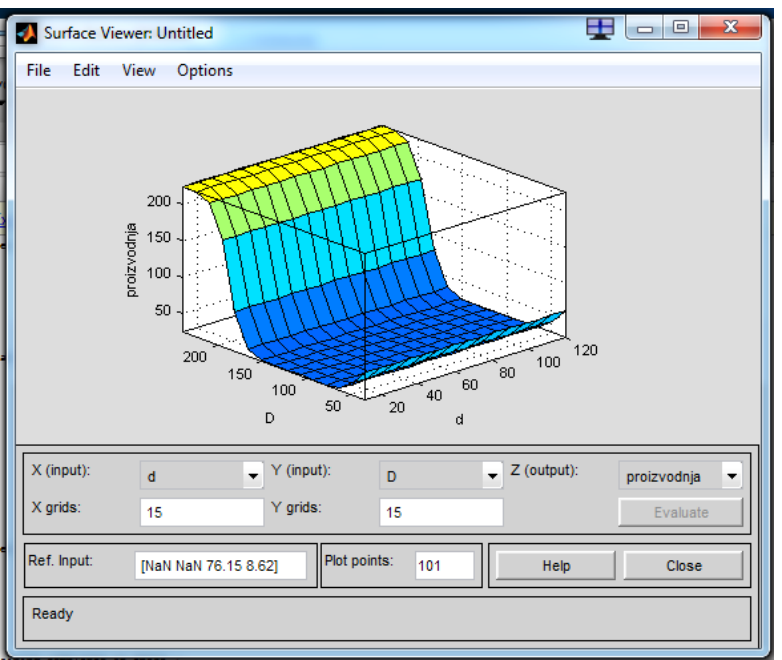

a) $T_{p r}=f(d, D)$

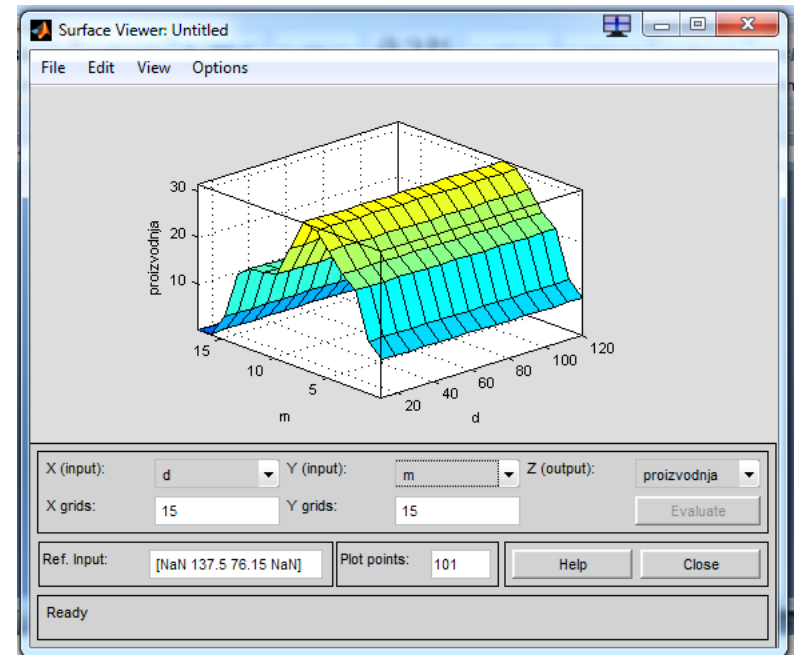

c) $T_{p r}=f(d, m)$

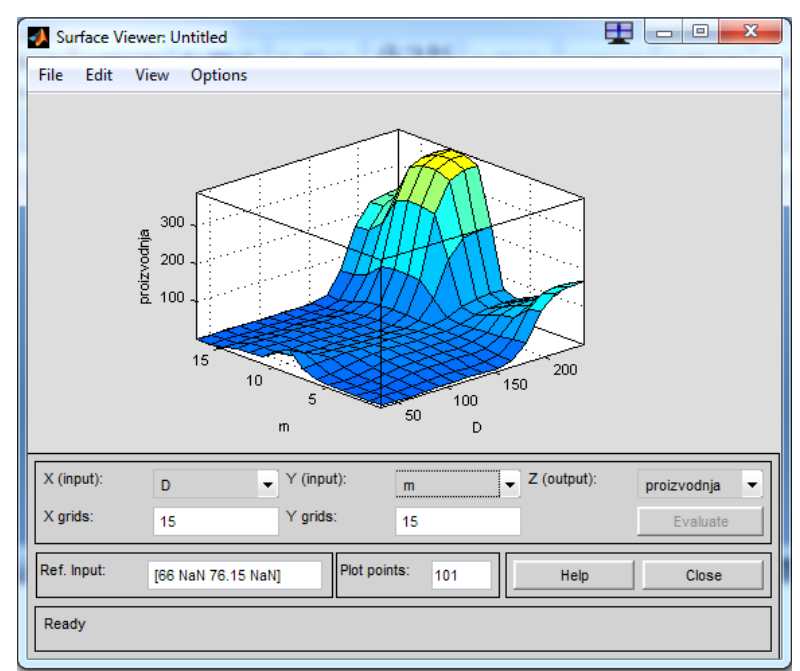

e) $T_{p r}=f(D, m)$

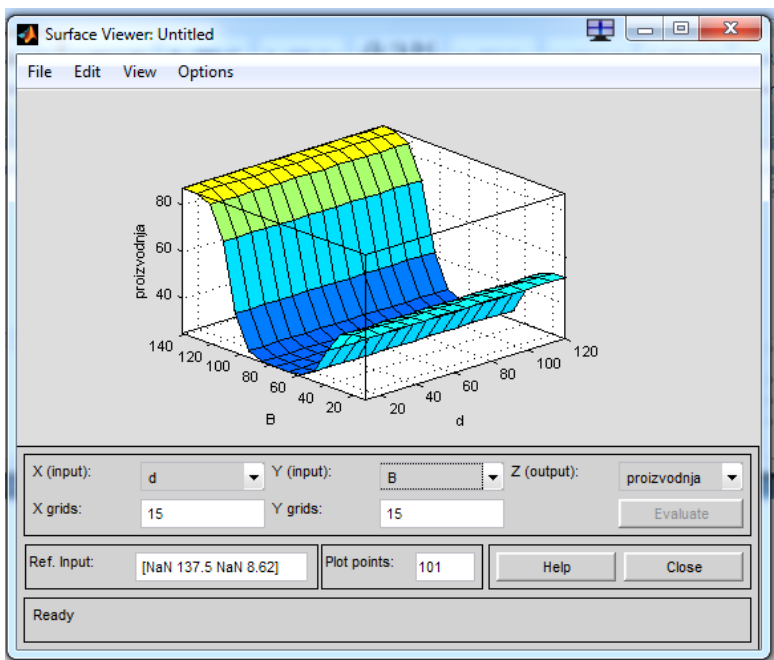

b) $T_{p r}=f(d, B)$

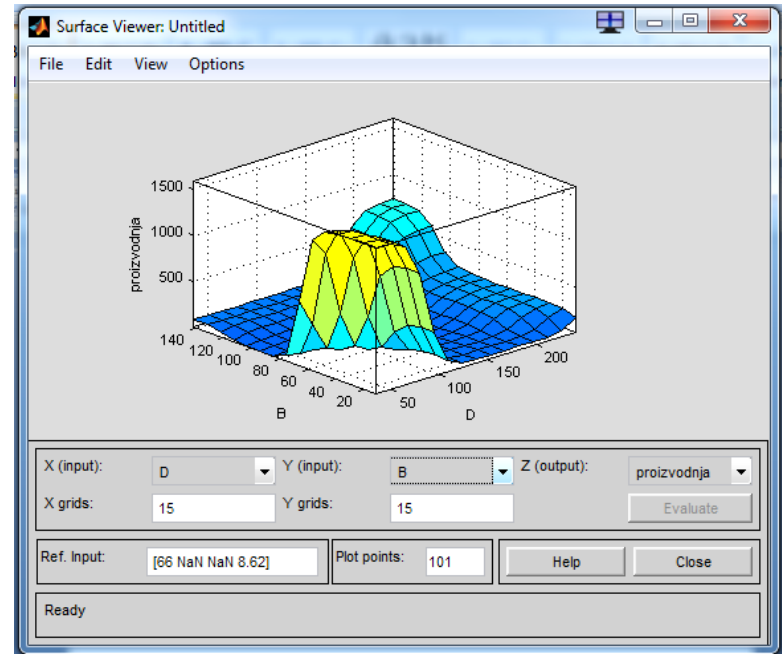

d) $T_{p r}=f(D, B)$

Figure 3: Graphical representation of costs of the production stage $\left(T_{p r}\right)$.

The results of training, testing and validation of the aforementioned fuzzy neural network for determining the costs of development, production, use and recycling of the new product are shown in Table $\mathrm{V}$. 
Todic, Cosic, Maksimovic, Tasic, Radakovic: Model for Simulation of Life Cycle Costs at ...

Table V: The results of training, testing and validation of the selected fuzzy neural network.

\begin{tabular}{|l|c|c|c|c|}
\hline \multicolumn{1}{|c|}{ Error amount } & Development & Manufacturing & Use & Recycling \\
\hline Error for 1000 epochs & 0.46128 & 2.4905 & 1.6646 & 0.4135 \\
\hline Training error & $0.46132 \%$ & $2.491 \%$ & $1.665 \%$ & $0.41355 \%$ \\
\hline Testing error & $2.2447 \%$ & $10.3441 \%$ & $6.9041 \%$ & $1.8401 \%$ \\
\hline Validation error & $0.31506 \%$ & $1.7024 \%$ & $1.1307 \%$ & $0.28027 \%$ \\
\hline
\end{tabular}

Using the trained fuzzy neural networks and entering the appropriate input data for the single row angular contact ball bearing the costs of all stages of the life cycle of these products were determined, Table VI.

Table VI: Life cycle costs of the single row angular contact ball bearing.

\begin{tabular}{|c|c|c|c|c|c|c|c|c|c|}
\hline \multirow{3}{*}{ No. } & \multirow{2}{*}{\multicolumn{4}{|c|}{$\begin{array}{c}\text { Bearing dimensions and } \\
\text { mass }\end{array}$}} & \multirow{3}{*}{ Label } & \multicolumn{4}{|c|}{ Life cycle costs of bearings ( $€ /$ piece $)$} \\
\hline & & & & & & Development & Manufacturing & Use & Recycling \\
\hline & $d$ & $D$ & $B$ & $m$ & & $T_{r a}$ & $T_{p r}$ & $T_{u p}$ & $T_{r e}$ \\
\hline 1. & 90 & 160 & 30 & 2.30 & $7218 \mathrm{BE}$ & 4.72 & 29.90 & 19.60 & 8.55 \\
\hline 2. & 100 & 180 & 34 & 3.30 & $7220 \mathrm{BE}$ & 6.30 & 34.30 & 22.60 & 9.42 \\
\hline 3. & 105 & 190 & 36 & 3.95 & $7221 \mathrm{BE}$ & 7.82 & 43.70 & 28.90 & 10.9 \\
\hline 4. & 110 & 200 & 38 & 4.60 & $7222 \mathrm{BE}$ & 9.57 & 59.40 & 39.60 & 13.2 \\
\hline 5. & 120 & 215 & 40 & 6.10 & $7224 \mathrm{BE}$ & 10.4 & 58.50 & 39.00 & 11.9 \\
\hline 6. & 130 & 230 & 40 & 6.95 & $7226 \mathrm{BE}$ & 10.70 & 59.60 & 39.80 & 12.6 \\
\hline
\end{tabular}

For the market price of the observed group of single row angular contact ball bearings $\left(C_{T}\right)$, determined by the corresponding product competitor in the market, the actual profit for specific bearing dimensions was determined using the Eq. (1), as shown in Table VII.

Table VII: Assessment of profitability of the observed bearing group.

\begin{tabular}{|c|c|c|c|c|c|c|c|c|}
\hline \multirow{2}{*}{ No. } & \multicolumn{4}{|c|}{ Bearing dimensions and mass } & \multirow{2}{*}{ Label } & $C_{T}$ & $T_{r a+} T_{p r}$ & $C_{T}-\left(T_{r a}+T_{p r}\right)$ \\
\hline & $d$ & $D$ & $B$ & $m$ & & \multicolumn{3}{|c|}{$(€ /$ piece $)$} \\
\hline 1. & 90 & 160 & 30 & 2.30 & $7218 \mathrm{BE}$ & 35.71 & 34.62 & 1.09 \\
\hline 2. & 100 & 180 & 34 & 3.30 & $7220 \mathrm{BE}$ & 41.71 & 40.60 & 1.11 \\
\hline 3. & 105 & 190 & 36 & 3.95 & $7221 \mathrm{BE}$ & 53.62 & 51.52 & 2.10 \\
\hline 4. & 110 & 200 & 38 & 4.60 & $7222 \mathrm{BE}$ & 71.27 & 68.97 & 2.30 \\
\hline 5. & 120 & 215 & 40 & 6.10 & $7224 \mathrm{BE}$ & 71.00 & 68.90 & 2.10 \\
\hline 6. & 130 & 230 & 40 & 6.95 & $7226 \mathrm{BE}$ & 72.80 & 70.30 & 2.50 \\
\hline
\end{tabular}

\section{DISCUSSION}

In the observed company the achieved profit in the production of a group of single row angular contact ball bearings is satisfactory. Therefore, this product is introduced in the expansion of the existing production program of rolling bearings. The increase in profits from the production of this group of bearings in the observed company can be ensured by reducing the costs of production and development.

Profitability in the production of these bearings in the observed enterprise can be increased by improving the existing or introducing new, more efficient lower-cost production processes. Alterations to the design and materials for the production of these bearings in order to reduce the cost of production are not possible due to functional requirements and standards required for this type of product.

It is not necessary to evaluate the single row angular contact ball bearings by comparing their costs of use with the corresponding costs of competitor products, because the origin, or the manufacturer, are unlikely to affect the installation costs. 
The main advantage of the developed algorithm in relation to the algorithms that relate to solving similar tasks is reflected in the possibility of its application for assessing and managing the costs of a single phase, and total life cycle cost of the new product.

\section{CONCLUSIONS}

The developed model allows managing the costs of individual stages of life cycle at the developmental stage. Thus, determining the costs for specific variations of conceptual and preliminary development of new products means adopting solutions that provide the accomplishment of the target profit and market competitiveness of the product in terms of its use or recycling.

Product life cycle cost management is particularly important, both in the stage of development and in the stage of use of new products. Based on market feedback, using the developed model, the ways of improving the realized products are directed according to the market demand which is one of the fundamental tasks of modern PLM systems.

More efficient use of the developed model can be ensured by automation of certain stages of model application including automated identification and selection of similarly realized products for which the life cycle costs are known.

The developed algorithm to for simulating and managing the costs of product development can also be applied in other industries, such as construction, textile, electronics, furniture production, etc.

\section{REFERENCES}

[1] Pahl, G.; Beitz, W.; Feldhusen, J.; Grote, K.-H. (2007). Engineering Design - A Systematic Approach, $3^{\text {rd }}$ edition, Springer-Verlag, London

[2] Nazari-Shirkouhi, S.; Keramati, A.; Rezaie, K. (2015). Investigating the effects of customer relationship management and supplier relationship management on new product development, Technical Gazette, Vol. 22, No. 1, 191-200, doi:10.17559/TV-20140623130536

[3] Cerjakovic, E.; Topcic, A.; Tufekcic, D.; Veza, I. (2015). Influence of structure of manufacturing system and amount of investment on production costs, Technical Gazette, Vol. 22, No. 3, 771780, doi:10.17559/TV-20140307103216

[4] Herrmann, J. W.; Cooper, J.; Gupta, S. K.; Hayes, C. C.; Ishii, K.; Kazmer, D.; Sandborn, P. A.; Wood, W. H. (2004). New directions in design for manufacturing, Proceedings of the $8^{\text {th }}$ Design and Engineering Technical Conference (ASME DETC 2004), 853-861

[5] Niazi, A.; Dai, J. S.; Balabani, S.; Seneviratne, L. (2005). Product cost estimation: technique classification and methodology review, Journal of Manufacturing Science and Engineering, Vol. 128, No. 2, 563-575, doi:10.1115/1.2137750

[6] Castro-Santos, L.; Diaz-Casas, V. (2014). Life-cycle cost analysis of floating offshore wind farms, Renewable Energy, Vol. 66, 41-48, doi:10.1016/j.renene.2013.12.002

[7] Folgado, R.; Pecas, P.; Henriques, E. (2010). Life cycle cost for technology selection: A case study in the manufacturing of injection moulds, International Journal of Production Economics, Vol. 128, No. 1, 368-378, doi:10.1016/j.ijpe.2010.07.036

[8] Xu, Y.; Elgh, F.; Erkoyuncu, J.A.; Bankole, O.; Goh, Y.; Cheung, W. M.; Baguley, P.; Wang, Q.; Arundachawat, P.; Shehab, E.; Newnes, L.; Roy, R. (2012). Cost engineering for manufacturing: Current and future research, International Journal of Computer Integrated Manufacturing, Vol. 25, No. 4-5, 300-314, doi:10.1080/0951192X.2010.542183

[9] Johnson, M.; Kirchain, R. (2009). Quantifying the effects of parts consolidation and development costs on material selection decisions: A process-based costing approach, International Journal of Production Economics, Vol. 119, No. 1, 174-186, doi:10.1016/j.ijpe.2009.02.003

[10] Hasangholipour, T.; Khodayar, F. (2010). A novel optimized neural network model for cost estimation using genetic algorithm, Journal of Applied Sciences, Vol. 10, No. 6, 512-516, doi: $\underline{10.3923 / j a s .2010 .512 .516}$ 
[11] Liu, H. (2010). Cost estimation and sensitivity analysis on cost factors: A case study on Taylor kriging, regression and artificial neural networks, The Engineering Economist, Vol. 55, No. 3, 201-224, doi:10.1080/0013791X.2010.495823

[12] Deng, S.; Yeh, T.-H. (2011). Using least squares support vector machines for the airframe structures manufacturing cost estimation, International Journal of Production Economics, Vol. 131, No. 2, 701-708, doi:10.1016/j.ijpe.2011.02.019

[13] Duran, O.; Maciel, J.; Rodriguez, N. (2012). Comparisons between two types of neural networks for manufacturing cost estimation of piping elements, Expert Systems with Applications, Vol. 39, No. 9, 7788-7795, doi:10.1016/j.eswa.2012.01.095

[14] Mirdamadi, S.; Etienne, A.; Hassan, A.; Dantan, J. Y.; Siadat, A. (2013). Cost estimation method for variation management, Procedia CIRP, Vol. 10, 44-53, doi:10.1016/j.procir.2013.08.011

[15] Cao, Y.; Zhang, H.; Mao, J.; Yang, J. (2010). Novel cost-tolerance model based on fuzzy neural networks, Proceedings of the Institution of Mechanical Engineers, Part B: Journal of Engineering Manufacture, Vol. 224, No. 11, 1757-1765, doi:10.1243/09544054JEM1789

[16] Huang, X. X.; Newnes, L. B.; Parry, G. C. (2012). The adaptation of product cost estimation techniques to estimate the cost of service, International Journal of Computer Integrated Manufacturing, Vol. 25, No. 4-5, 417-431, doi:10.1080/0951192X.2011.596281

[17] Liu, H.; Gopalkrishnan, V.; Quynh, K. T. N.; Ng, W.-K. (2009). Regression models for estimating product life cycle cost, Journal of Intelligent Manufacturing, Vol. 20, No. 4, 401-408, doi: $10.1007 / \mathrm{s} 10845-008-0114-4$

[18] Koren, R.; Prester, J.; Buchmeister, B.; Palčič, I. (2016). Do organisational innovations have impact on launching new products on the market?, Strojniški vestnik - Journal of Mechanical Engineering, Vol. 62, No. 6, 389-397, doi:10.5545/sv-jme.2016.3470

[19] Wu, S. B.; Gu, X.; Wu, G. D.; Zhou, Q. (2016). Cooperative R\&D contract of supply chain considering the quality of product innovation, International Journal of Simulation Modelling, Vol. 15, No. 2, 341-351, doi:10.2507/IJSIMM15(2)CO7

[20] Wang, H. S.; Wang, Y. N.; Wang, Y. C. (2013). Cost estimation of plastic injection molding parts through integration of PSO and BP neural network, Expert Systems with Applications, Vol. 40, No. 2, 418-428, doi:10.1016/j.eswa.2012.01.166

[21] Mitrofanov, S. P. (1976). Naučnaja organizacija mašinostroiteljnova proizvodstva, Mašinostrojenije, Lenjingrad (in Russian)

[22] Pratt, M. J. (2001). Introduction to ISO 10303 - the STEP standard for product data exchange, Journal of Computing and Information Science in Engineering, Vol. 1, No. 1, 102-103, doi: $10.1115 / 1.1354995$

[23] Gracanin, D.; Lalic, B.; Beker, I.; Lalic, D.; Buchmeister, B. (2013). Cost-time profile simulation for job shop scheduling decisions, International Journal of Simulation Modelling, Vol. 12, No. 4, 213-224, doi:10.2507/IJSIMM12(4)1.237

[24] Rohde, D.; Storga, M.; Marjanovic, D. (2015). Design rationale capturing model for use during the embodiment phase of the product design, Transactions of FAMENA, Vol. 39, No. 1, 27-42 